\title{
Fluctuations in Protein Levels of Tobacco Leaves and Consequences for Extractability *
}

\author{
by Donald W. DeJong and James A. Saunders \\ Tobacco Research Laboratory, Plant Genetics and Germplasm Institute, \\ Beltsville Agricultural Research Center, U.S. Department of Agriculture, \\ Belssille, Maryland, U.S.A.
}

\section{SUMMARY}

Greenhouse and field experiments were conducted to evaluate the effect of time, cultural conditions and genetic factors on protein extractability from tobacco leaves. Leaf protein was periodically extracted from green tobacco from time of transplanting through early senescence. Intensive sampling revealed substantial fluctuations in protein concentrations superimposed upon an age-related decline in protein levels with approaching plant maturity. Predictably, these oscillations affected the degree of protein extractability. Combined totals of the three major soluble protein fractions, viz. the green chlorophyll/protein complex, the white Fraction I protein (cryoprecipitate), and the white Fraction II protein (thermoprecipitate), deviated occasionally from protein values in unfractionated homogenates, but the fluctuation trends were similar. Investigations of variations in protein extractability among greenhousegrown tobacco and selected genotypes grown under field conditions revealed that protein fluctuations during plant development are a common phenomenon. It is concluded that the occurrence of periodic fluctuations in total protein concentration and in the amount of extractable protein can severely distort estimates of leaf protein yields that are based upon insufficient numbers of samples and prolonged intervals between sampling.

\footnotetext{
* Received: 6th March 1985 - accepted: 29th October 1985.
}

\section{ZUSAMMENFASSUNG}

An im Gewāchshaus und im Freiland gezogenen Tabakpflanzen wurde untersucht, inwieweit zeitliche und genetische Faktoren sowie die Anbautechnik die Extrahierbarkeit von Protein aus dem Blattgut beeinflussen. Das Protein wurde aus dem grünen Tabakblatt in bestimmten Zeitabständen von der Umpflanzung an bis in die erste Phase der Alterung der Pflanze hinein extrahiert. An umfangreichem Probematerial zeigten sich über einen altersbedingten, mit zunehmendem Reifegrad zu beobachtenden Rückgang des Proteingehaltes hinaus erhebliche Schwankungen der Proteinkonzentration. Wie es vorauszusehen war, wurde die Extrahierbarkeit des Proteins durch diese Schwankungen beeinflußt. Die Mengen der drei wichtigsten löslichen Proteinfraktionen - der grüne, an das Chlorophyll gebundene Proteinkomplex, das weiße Fraktion-I-Protein (Gefrierausfällung) und das weiße Fraktion-II-Protein (Hitzeausfällung) - wichen insgesamt manchmal von dem Proteingehalt der nicht fraktionierten homologen Proben $a b$, in der Tendenz waren die Schwankungen aber ähnlich. An im Gewächshaus gezogenen Tabakpflanzen und ausgewählten Freilandgenotypen zeigte sich, daß die Extrahierbarkeit des Proteins während der Wachstumsperiode allgemein schwankt. Folgende Schlußfolgerung wird gezogen: durch periodische Schwankungen in der Gesamtproteinkonzentration und in der Extrahierbarkeit des Proteins kōnnen Abschätzungen des zu erwartenden Pro- 
teinertrages in erheblichem Maße verfälscht sein, wenn die den Berechnungen zugrundeliegende Probenanzahl zu klein ist und die Proben in zu langen Zeitabstānden entnommen worden sind.

\section{RESUME}

Au moyen d'expériences effectuées sur des plantes de tabac cultivées en serre et én plein champ, on a étudié quel était l'effet du temps, des facteurs génétiques ainsi que des conditions de culture sur les possibilités d'extraction des protéines des feuilles de tabac. Les protéines ont été périodiquement extraites des feuilles de tabac vert, depuis le stade de la transplantation jusqu'à la phase initiale de sénescence de la plante. Un large échantillonnage a permis de mettre en évidence des fluctuations considérables de la concentration protéinique lesquelles se superposent à la diminution de la teneur protéinique que l'on observe au fur et à mesure de la croissance de la plante. Comme on pouvait le prévoir, ces fluctuations ont une incidence sur la facilité d'extraction. Les quantités des trois fractions protéiniques solubles les plus importantes, à savoir le complexe protéinique chlorophyllien vert, la fraction blanche I (cryoprécipitée) et la fraction blanche II (thermoprécipitée), s'écartent parfois globalement des teneurs protéiniques des homogénéisats avant extraction, mais, dans l'ensemble, on constate des tendances de variation analogues. La variation de l'aptitude à l'extraction protéinique pendant la période de croissance $s$ 'avère être un phénomène commun, tant dans le cas des plantes cultivées en serre que dans celui du tabac génétiquement sélectionné cultivé en plein champ. Il en résulte par conséquent que les fluctuations périodiques de la concentration protéinique totale et de la teneur en protéines extractibles risquent de fausser considérablement les estimations du rendement en protéines si les calculs sont basés sur un nombre trop faible d'échantillons et si ces derniers sont prélevés à des fréquences insuffisantes.

\section{INTRODUC'TION}

The prospects for isolating an edible protein byproduct from green foliage has excited considerable popular interest and stimulated scientific research that has been international in scope (28). It is generally recognized that isolation of leaf protein from green plants requires initial separation of the protein in fluid form from the fiber residue and subsequent concentration of the protein to a solid form by precipitation techniques.

Some investigators have chosen to emphasize mechanical equipment development $(22,26)$, others processing methodology (17). Since the pioneering leaf protein work of PIRIE, during the 1940's (23), a wide range of plant species and extraction protocols have been examined with a view to optimizing the process. Both temperate climate (4) and tropical plant species (27) have been surveyed to identify suitable candidates for extraction of leaf protein. A number of patents have been issued for claims relating primarily to processing techniques $(1,2,8,15,30)$. Much of the commercially oriented leaf protein work has involved alfalfa because of its pre-eminence as a forage crop $(3,11)$. Within the past decade, information published by several groups has shown tobacco to be an excellent leaf protein source $(5,10,13,16,25,29,31)$. Two features of tobacco have provided the major impetus for this selection: [1] The uniqueness of tobacco as a source of a highly pure crystalline protein fraction, i.e. Fraction I (ribulose bisphosphate carboxylase/oxygenase) (12) and [2] The potential for coupling the leaf extraction procedure with alternative processing methods to achieve a less hazardous smoking product $(6,18)$.

Two important criteria of leaf protein recovery are yield and ease of extraction. Unfortunately, much of the published data on yields have been based upon unrealistic laboratory or greenhouse conditions which frequently differ substantially from large-scale field conditions (10). The optimal stage for leaf protein extraction is often thought to occur when the protein concentration curve reaches its maximum point. As the plants mature, however, degradative processes in the leaves begin to predominate with substantial increases in protease activity (7). As a consequence, the computation of biomass yield in conjunction with protein extractability at an assumed optimal stage of development does not always project an accurate assessment of protein productivity [e.g. (19)]. There have been hints in the literature that protein concentrations rise and fall periodically during growth and development of the plant. For example, LowE and SHERN (21) clearly demonstrated pronounced fluctuations in tobacco protein yields in their graphs but made no reference to the phenomenon in the text. In previous work we have also observed day-to-day protein oscillations affecting different leaf positions in a similar manner, implying that the whole plant is systematically involved in protein oscillatory behavior (9). To examine the oscillation problem in detailed realistic terms, we deliberately chose procedures that, although scaled down for sample size, would provide a practical system for protein isolation. The rationale for this decision was to avoid criticism that the methods were not applicable to an industrial approach (10). Parameters for extraction included: [1] Maceration of leaves without additional process water, [2] Use of inexpensive chemicals to control $\mathrm{pH}$ and suppress oxidation reactions, and [3] Suitability for rapid but low speed centrifugation steps to achieve solid/liquid separations.

Preliminary experiments indicated that protein concentrations in extracts from greenhouse-grown tobacco plants were consistently lower than those of fieldgrown tobacco. To examine some of the effects imposed by cultural conditions on extraction of leaf protein we compared greenhouse-grown plants and conventionally as well as densely spaced field-grown plants. The major objectives of this investigation were 
to document changes in the relative abundance of protein subfractions during plant growth and to determine the effect of fluctuations in protein concentrations on extractability.

\section{MATERIALS AND METHODS **}

\section{Plant Materials}

All experiments and protocols reported in this paper are divided into two sections to facilitate communication. At first, a protocol was developed for plants grown in the greenhouse and for the corresponding controls grown under typical field conditions for Maryland tobacco (protocol A). Based upon data from the initial results, both the extraction procedures and the cultural conditions for the growth of the tobacco were modified to simplify recovery of leaf protein (protocol B).

Protocol A: Three cultivars of Nicotiana tabacum including a Maryland type (Md. 872), a Burley type (Burley 21) and a cigar filler type (Pennbel 69) were grown under greenhouse and field conditions in a randomized block design. At approximately two-week intervals, starting at the transplanting stage and continuing throughout the growing season, samples were harvested, weighed and extracted for protein as outlined below.

Protocol B: Tobacco plants used in this phase of the study were Maryland 609, unless otherwise noted. Plants were grown in densely packed $s w a r d s\left(18\right.$ plants $\left./ \mathrm{m}^{2}\right)$ much closer than is customary in commercial practices (1.5-3.0 plants $/ \mathrm{m}^{2}$ ). Limited plantings of selected cultivars and experimental tobacco genotypes were established with the following: Maryland Mammoth, lownicotine Burley, Burley Mammoth, Yellow Mammoth, Mammoth Yellow, T.I. 1329, and T.I. 1602. For evaluating the influence of plant maturation, whole plants including stalk and leaves from randomly selected 2-meter square blocks were harvested from the densely cropped plantation. At each sampling date three separate blocks of plants were cut, counted and weighed. Values were recorded for both total plants and leaves only. Protein extracts were prepared from $1.5 \mathrm{~kg}$ of leaves stripped from representative plants. Moisture determinations were made with a CoMpU-TRAc* moisture analyzer (model 2A). Finally, the stripped stalks were weighed to obtain a leaf/stalk ratio.

\section{Extraction of Leaf Protein}

Protocol A: The technique of Lowe (20) with slight modifications was used to extract and separate the leaf protein fractions. At time of harvest, $0.5 \mathrm{~kg}$ to $1.0 \mathrm{~kg}$ of leaf material was stripped from the plants, weighed, and macerated in a Waring Blendor with $2 \times \mathrm{NaCl}$ containing $0.5 \mathrm{ml}$ mercaptoethanol per $100 \mathrm{ml}$ liquid at a ratio of 5 to 1 (liquid/leaf). The homogenate was pressed through nylon bags by an electrically driven hydraulic ram (Model 240-S, Norwalk Mfg. Co.). The filtrate was heated momentarily to $50^{\circ} \mathrm{C}$, then cooled to $20^{\circ} \mathrm{C}$ in an ice bath. The $\mathrm{pH}$ was adjusted to 7.4 by the addition of $1 \mathrm{M}$ tris(bydroxymethyl)methylamine (Tris) and $10 \%(w / v) \mathrm{Na}_{2}$ EDTA was added in the ratio of $2 \mathrm{ml} / 100 \mathrm{ml}$ of filtrate. The $\mathrm{pH}$ was readjusted to 7.4 and the mixture was centrifuged at $16,000 \times \mathrm{g}$ for $30 \mathrm{~min}$ at $4^{\circ} \mathrm{C}$. The supernatant was loaded onto the top of a column $(9.5 \mathrm{~cm} \times 40 \mathrm{~cm})$ packed with coarse Sephadex G-50 and equilibrated with $25 \mathrm{~mm}$ Tris-HCl buffer ( $\mathrm{pH} 8.0$ ) containing $0.2 \mathrm{~mm}$ disodium EDTA. The elution of protein from the column with equilibration buffer was monitored by adding $10 \%(w / w)$ trichloroacetic acid (TCA) dropwise to aliquots of the eluent, until a white precipitate developed. The eluent portion containing the protein was collected and stored at $4^{\circ} \mathrm{C}$ for 2 days. Fraction $I$ protein which crystallized from solution during storage was washed with acetone to remove any residual pigments and subsequently rinsed with water to remove the acetone residue. The washed sample was lyophilized and weighed to determine yields.

Fraction II protein was recovered by adjusting the mother liquor to $\mathrm{pH} 4.5$ with concd. $\mathrm{HCl}$ and the precipitate was washed with acetone followed by water rinses. The residue was lyophilized to yield an off white powder.

Experiments with field-grown and greenhouse-grown plants followed the same procedure except that, for the latter, smaller quantities of plant material were used. For both plant groups all extraction and isolation procedures were performed in duplicate at every sampling date for each variety tested.

Protocol B: The second phase of the experiment was designed to simplify the extraction and fractionation procedures in order to evaluate potential commercialization of the operation. In view of the fluctuations previously observed in the leaf protein concentrations harvesting intervals were much shorter. Freshly harvested leaves were macerated with an extrusion grinder, while gradually adding a mixture of dry pulverized sodium hydroxide (at $0.6 \mathrm{~g} / \mathrm{kg}$ ) and sodium metabisulfite (at $3 \mathrm{~g} / \mathrm{kg}$ ). The objective for adding $\mathrm{NaOH}$ was to obtain a homogenate with $\mathrm{pH}$ in the range of 5.8-6.2 whereas sodium metabisulfite served as an antioxidant. After maceration, $1.0 \mathrm{~kg}$ of homogenate was poured into cloth filter bags and the green juice was pressed out with the Norwalk Model 240-S ram. Juice und fiber weights were recorded and moisture measurements were taken for both fractions. To determine total extractable protein one portion of the green filtrate was heated at $80^{\circ} \mathrm{C}$ for $10 \mathrm{~min}$, rapidly cooled, and centri-

\footnotetext{
* Tempe, Ariz, U.S.A.

t* Mention of a trademark or proprietary product does not constitute guarantee or warraty of the product by the U.S. Department of Agriculture, and does not imply its approval to the exclusion of other products that may also be suitable.
} 
Figure 1.

Fraction I and Fraction II protein extracted after transplanting from greenhouse and field-grown tobacco (protocol A).

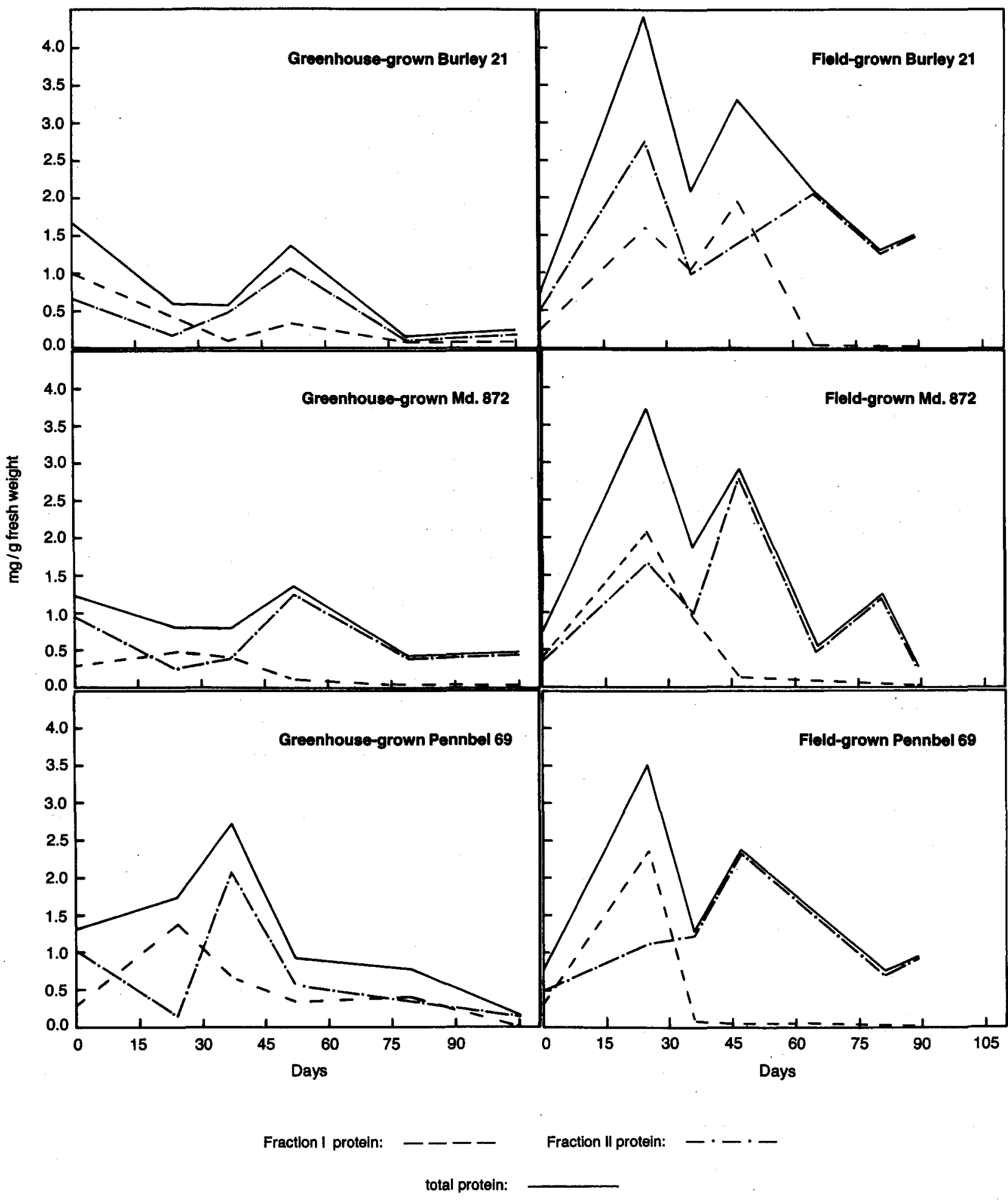


fuged. This and all subsequent centrifugations were performed at $1400 \times \mathrm{g}$ for $30 \mathrm{~min}$. Another aliquot of filtrate was subjected to a three-stage sequential separation procedure. First, the $\mathrm{pH}$ of the solution was adjusted to $\mathrm{pH} 5.1$ with $50 \%(\mathrm{w} / \mathrm{v})$ citric acid and the precipitate was pelleted by centrifugation. Secondly, the clear amber supernatant was cooled to $10^{\circ} \mathrm{C}$ and stored for 24 hours or more until a white flocculent precipitate appeared and this cryoprecipitate was sedimented by centrifugation. Finally, the protein remaining in solution was coagulated by heating the sample at $80^{\circ} \mathrm{C}$ for 10 minutes and the thermoprecipitate was collected by centrifugation.

The leaf fiber fractions were rapidly dried with a fluid bed dryer", and the protein pellets were oven dried overnight at $80^{\circ} \mathrm{C}$. A $25 \mathrm{ml}$ aliquot of the clarified brown supernatant was preserved with $0.05 \%(w / v)$ sodium azide for later analyses.

\section{Analyses}

Protocol A: The data in Figure 1 were based on gravimetric measurements of both Fraction I and Fraction II proteins precipitated as described above. Total protein in this figure is the sum of the combined weights of Fraction I and Fraction II protein.

Protocol B: Total organic nitrogen was determined by the Kjeldahl procedure and converted into crude protein values by the appropriate equations. The phenolic and specific anion concentrations of the supernatant also were measured.

1. Crude Protein: Protein was analyzed by the Brinkmann $\mathrm{Kjeldahl}$ apparatus which involved digestion of the sample with sulfuric acid - selenium catalyst, steam distillation of the alkali adjusted digest, and titration of the volatilized ammonia with standard acid (Sybron/ Brinkmann Bulletin PB-268). Volume of titrant was calibrated for nitrogen and protein concentration calculated on the basis of a digested sample of pure bovine serum albumin. Three successive analyses were made for each of the three replications.

2. Non-protein Nitrogen: Each sample of fiber was extracted twice with $0.5 \%(\mathrm{v} / \mathrm{v})$ acetic acid at $50^{\circ} \mathrm{C}$ for $10 \mathrm{~min}$ in a ratio of $1 \mathrm{~g}$ sample $/ 50 \mathrm{ml}$ solvent. After vacuum filtration through Whatman $\$ 41$ filter paper on a Büchner funnel, the extracted fiber was digested and Kjeldahl values were determined. Non-protein nitrogen was calculated as the difference between this value and the Kjeldahl value.

3. Pbenolics: The phenol concentration of the deproteinized supernatant was measured with the ferricyanideaminoantipyrene reagent by the procedure described in Sybron/Brinkmann Bulletin \#BR-457 (33) except that the steam distillation step was omitted. Values were calibrated against chlorogenic acid, a major phenolic in tobacco.

† Lab-Line Instruments, Inc. (Model PRI).
4. Inorganic Anions (nitrate, phosphate, sulfate): $\mathrm{Hach}^{+}$ analytical kits were used to determine the anion concentration in the brown juice. Nitrate was determined by the cadmium reduction reaction (Hach $* 41100-12$ ), phosphate by the molybdenum blue reaction (Hach \#41100-16) and sulfate by measuring the turbidity resulting from reaction with barium chloride (Hach *4100-19).

\section{RESULTS}

In phase one of the study (protocol A), protein from tobacco leaf tissue was extracted from both greenhouse and field-grown plants during a 100 -day growing period. Fraction $I$ and Fraction II protein increased more rapidly in field-grown Burley 21 and Md. 872 than in comparably aged greenhouse-grown samples of the same varieties (Fig. 1). The Pennbel 69 greenhousegrown tobacco reached its peak of maximal protein 15-20 days ahead of the other varieties tested. Each of the three cultivars evaluated in the field reached maximum extractable protein between 20-30 days after transplanting. Following initial increases in both Fraction I and Fraction II protein in field-grown plants, total leaf protein declined quite rapidly during the succeeding two months. However, there were dramatic fluctuations in the amount of recoverable protein in both greenhouse and field-grown tobacco throughout the course of the growing season. For each cultivar evaluated, Fraction I protein declined at least two weeks earlier than Fraction II protein. In greenhousegrown plants, which were considerably smaller than the field-grown counterparts, the amounts of protein recovered per gram of leaf were usually much less than that of field-grown plants. The fluctuating patterns of recoverable protein in each cultivar of field-grown tobacco were similar in the early part of the growing season, Recoverable Fraction I protein decreased towards the end of the growing season first in Pennbel 69, then in Md. 872, while Burley 21 maintained a relatively bigh level until the 64th day after transplanting. Leaf protein recovery from greenhouse-grown plants fluctuated during the growing season, but fluctuations were less frequent and less extreme than in field-grown plants. These patterns suggested a fundamental physiological feature of tobacco growth and development.

In phase two of the study designated as protocol B, tobacco plants of cultivar Maryland 609 were spaced more closely and sampled more frequently over a time span of only 30 days. In addition, the extraction methodology was modified in order to simulate commercially relevant conditions. A flow chart of the protein fractionation procedure is shown in Fig. 2. Although total biomass of the whole plants increased throughout the entire month, the fresh weight of leaves diminished after the second week (Table 1). The close spacing

${ }^{+}$Hach Company, Loreland, Colo, U.S.A. 
Figure 2.

Flow chart of tobacco leaf protein fractionation (protocol B).

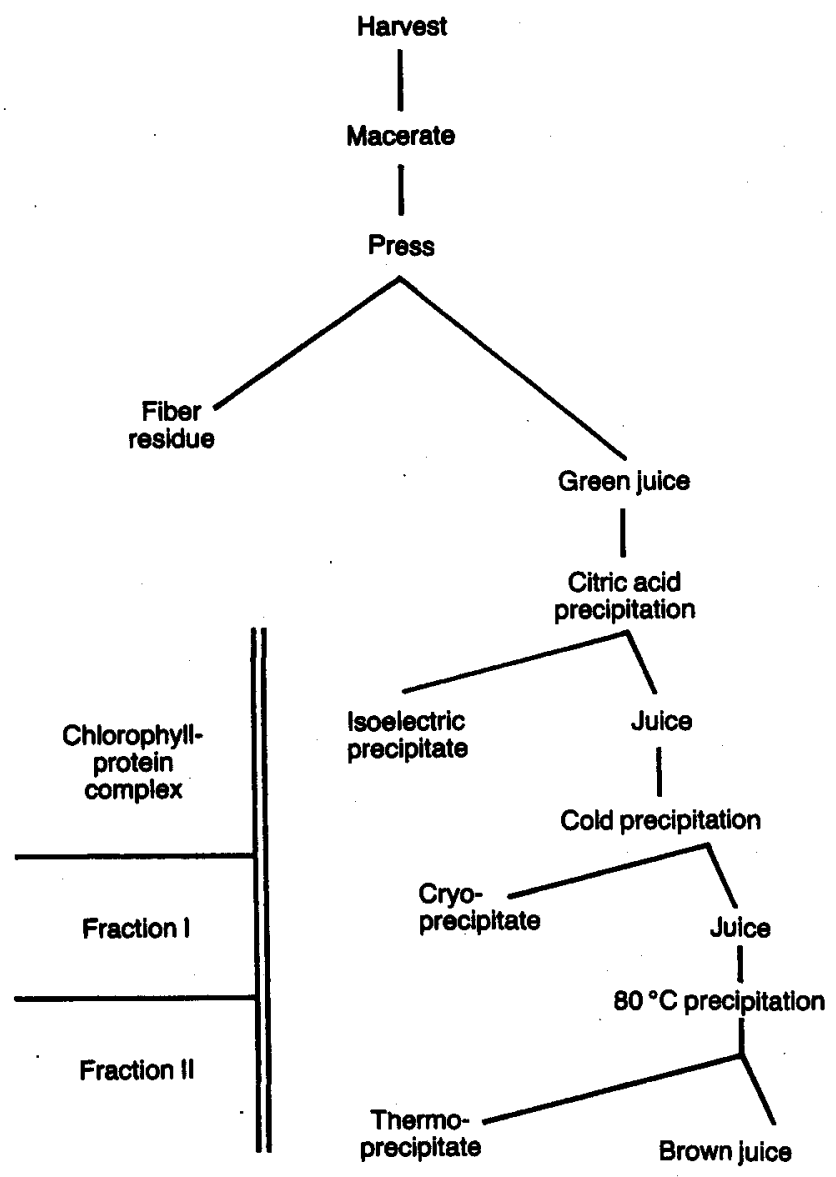

caused shaded leaves in the lower part of the canopy to senesce and fall; terminal growth was not sufficient to compensate for loss of the lowermost leaves. After the third week, leaf moisture levels declined 3\% (from $91.4 \%$ to $88.8 \%$ ) which was one cause of diminished protein recoveries (i.e. the "washout" effect). As a result, although the percent solids in the green filtrate increased as the season progressed, the actual amount of filtrate decreased as shown by the liquid/fiber ratios in the last column of Table 1. Residual moisture in the pressed fiber averaged $73.4 \%$ with extremes from $69.3 \%$ to $78.7 \%$.
Figure 3.

Tobacco leaf proteln extractabillty. Proteln concentration in tobacco leef material before and after extraction in relation to plant development (protocol B). Note: The difference between the two curves (shaded area) is not necessarily equivalent to the amount of protein recovered in the combined soluble fractions because of processing losses.

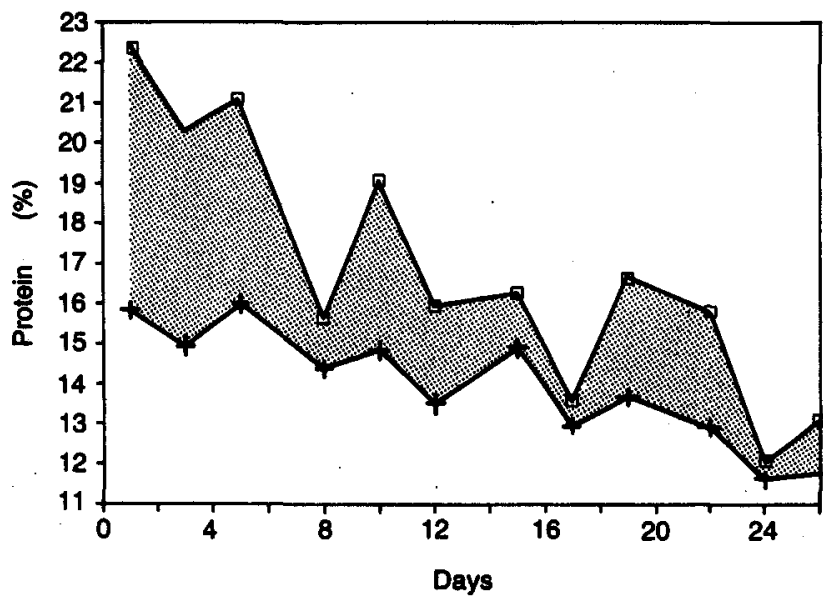

before extraction: $\square$ after extraction: +

Subfractionation of extracted protein into individual components yielded three major classes or fractions (Fig. 2). All three of these fractions are considered soluble proteins because they are contained in the filtrate. The amplitude of fluctuation was greater for the "soluble" or extractable protein than for the "non-soluble" or residual protein. Even so, the fluctuation patterns for the fiber before extraction resembled the patterns observed after extraction and removal of the soluble protein (Fig. 3). Although gentle heat (brief heating to $50^{\circ} \mathrm{C}$ followed by rapid cooling) has been frequently utilized to rid green leaf extracts of the chlorophyllbound protein, titration with $50 \%$ citric acid to $\mathrm{pH} 5.1$ was found to be an effective technique for destabilizing this fraction and obtaining a green precipitate. Subsequent fractionation of the white protein components was accomplished by a two-step procedure. The supernatant was stored at $10^{\circ} \mathrm{C}$ for $24-48 \mathrm{~h}$ and the residue removed by centrifugation. The resultant supernatant was heated at $80^{\circ} \mathrm{C}$ for 10 minutes and this residue removed by centrifugation.

The green chlorophyll-protein complex comprised $50 \%$ or more of the total extractable protein although the

Table 1.

Extraction parameters assoclated with yield potential for tobacco leaf proteln.

\begin{tabular}{c|c|c|c|c|c}
\hline Period & $\begin{array}{c}\text { Whole plants } \\
\text { (fresh weight) } \\
\left(\mathrm{kg} / \mathrm{m}^{2}\right)\end{array}$ & $\begin{array}{c}\text { Leaf only } \\
\text { (fresh welght) } \\
\left(\mathrm{kg} / \mathrm{m}^{2}\right)\end{array}$ & $\begin{array}{c}\text { Leaf moisture } \\
(\%)\end{array}$ & $\begin{array}{c}\text { Green juice } \\
\text { solids } \\
(\%)\end{array}$ & $\begin{array}{c}\text { Juice/flber } \\
\text { ratio }\end{array}$ \\
\hline 1st week & 4.67 & 3.25 & 91.9 & 5.1 & $5.5: 1$ \\
2nd week & 6.07 & 3.56 & 91.3 & 5.0 & $5.1: 1$ \\
3rd week & 6.54 & 3.51 & 91.4 & 5.4 & $4.9: 1$ \\
4th week & 7.06 & 3.00 & 88.8 & 7.9 & $3.3: 1$ \\
\hline
\end{tabular}


Figure 4.

Tobacco leaf protelns: Extractable green and white fractions.

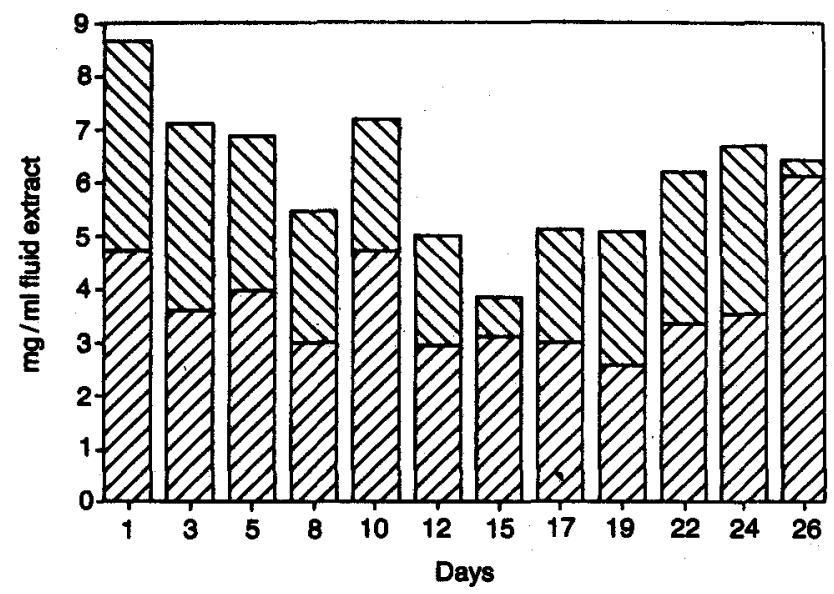

green: [ whlte:

relative proportions of green and white protein varied considerably (Fig. 4). The relative amounts of cryoprecipitate and thermoprecipitate also varied (Fig. 5). The cryoprecipitate obtained after removal of the green fraction consisted primarily of Fraction I protein, whereas the remaining protein removed from solution by heating to $80^{\circ} \mathrm{C}$ was a mixture of soluble proteins referred to as Fraction II protein. Fraction I yields initially decreased during successive harvests but at midseason increased again before dropping abruptly about the time of flowering. All of the isolated protein fractions showed increasing degrees of non-protein contamination as the season progressed (Table 2).

Phenolics are known to exert an adverse effect on extraction of plant proteins, particularly with respect to retention of enzyme activity. In order to minimize the enzymatic oxidation of plant polyphenols to their respective quinones, which covalently bind to proteins to form insoluble complexes, antioxidants are routinely added to extraction media. The degree of enzymatic browning is symptomatic of the extent of phenolic oxidation. Phenolic levels (as chlorogenic acid equivalents) in the deproteinized brown supernatants showed a fluctuating pattern with a steep rise in concentration on the last day of harvest (Fig. 6).

The percentage of the crude protein in the fiber attributable to non-protein nitrogen was somewhat variable (data not shown). However, it averaged less than 1/4 of the total Kjeldahl value.

The concentrations of sulfate, phosphate and nitrate anions present in the deproteinized supernatant of the tobacco leaf extract are presented in Table 3. Sulfate levels in the brown juice after protein removal were an order of magnitude higher than either of the other two anions. The three lowest values (on days 12, 17, and 24) for nitrate coincided with the lowest inflection points for protein concentration (cf. Fig. 3); however, this trend was not consistent in earlier sampling dates. Whether there is a direct relationship between nitrate
Figure 5.

Tobacco leaf protelne: Soluble white fractions, recovered by thermo and cryoprecipltation.

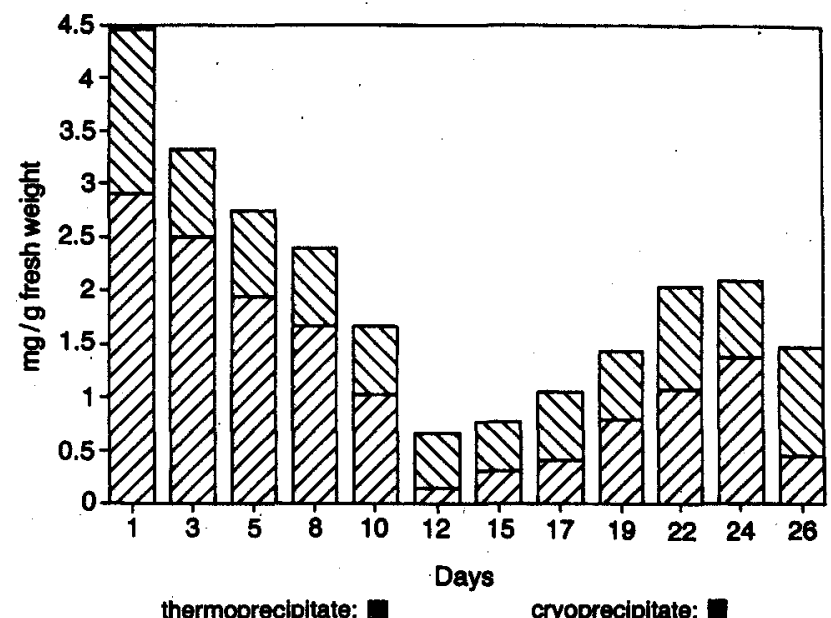

Flgure 6.

Tobacco leaf tractionation. Phenolic content in brown julce after deproteinization.

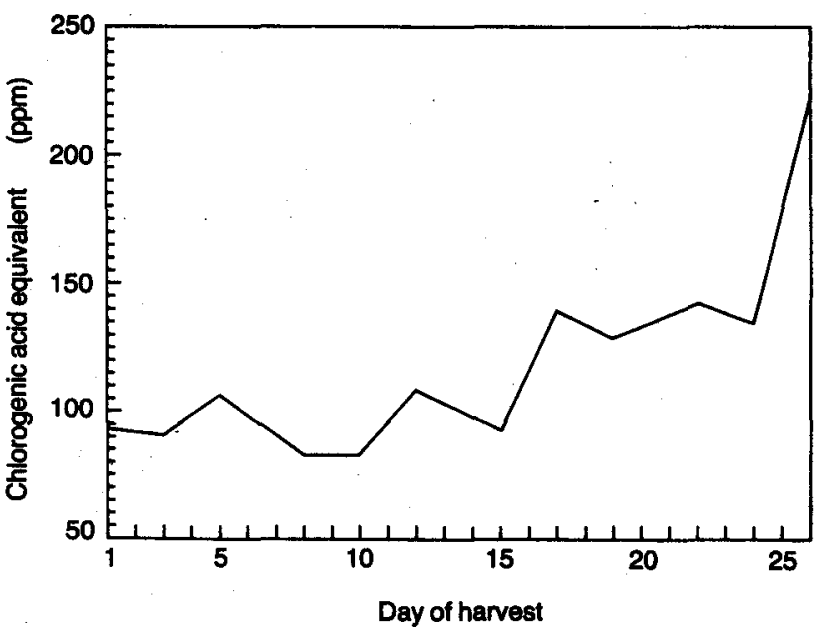

Table 2. Purity of recovered tobacco leaf proteln fractions.

\begin{tabular}{l|l|l}
\hline Time of harvest & \multicolumn{1}{|c|}{ Fraction } & Percent protein \\
\hline Early season & Total precipitate $\left(80^{\circ} \mathrm{C}\right)$ & $46.6 \pm 1.3$ \\
& Isoelectric precipitate & $34.7 \pm 4.1$ \\
& Cryoprecipitate & $92.7 \pm 2.4$ \\
& Thermoprecipitate & $86.4 \pm 3.4$ \\
\hline Midseason & Total precipitate $\left(80^{\circ} \mathrm{C}\right)$ & $40.8 \pm 1.0$ \\
& Isoelectric precipitate & $26.9 \pm 1.6$ \\
& Cryoprecipitate & $71.5 \pm 8.1$ \\
& Thermoprecipitate & $78.7 \pm 1.9$ \\
\hline \multirow{2}{*}{ Late season } & Total precipitate $\left(800^{\circ} \mathrm{C}\right)$ & $31.6 \pm 1.8$ \\
& Isoelectric precipitate & $21.2 \pm 2.9$ \\
& Cryoprecipitate & $50.7 \pm 5.2$ \\
& Thermoprecipltate & $70.1 \pm 7.0$ \\
\hline
\end{tabular}


Flgure 7.

Tobacco leaf protelns: Varletal dfferences among selected genotypes showing percent protein In unextracted and extracted flber (press cake). Second harvest was after two-week interval.

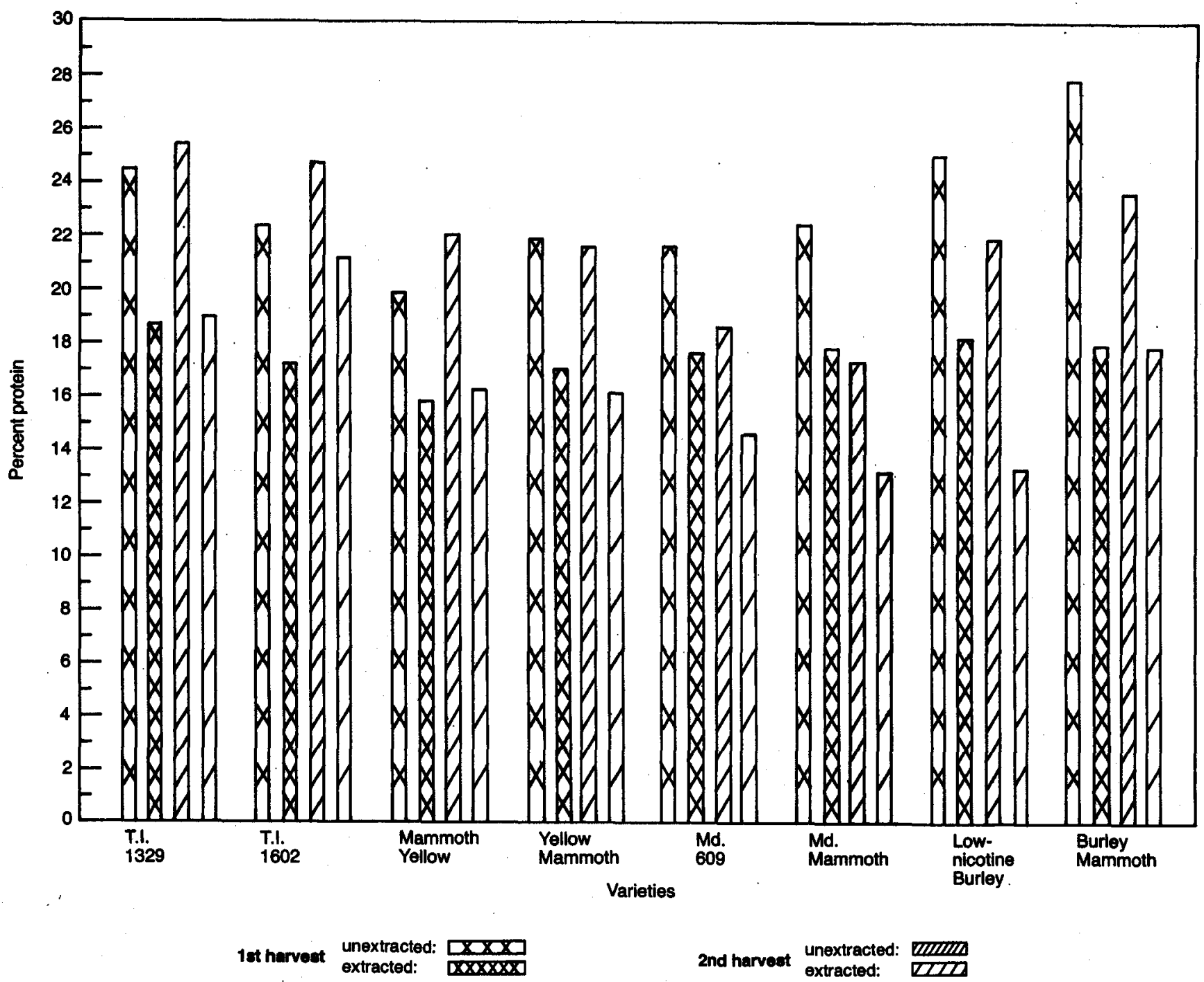

levels and protein concentrations is not known, although high nitrogen fertility tends to boost the content of nitrogenous compounds in plant tissues.

\section{Comparison of Protein Extraction from Selected Tobacco Genotypes}

Varieties for the second phase of these experiments (protocol B) were chosen on the basis of two criteria:

1. Plant babit: Hungarian types, short plants, early flowering behavior and Mammoth types, tall plants, late flowering behavior.

2. Alkaloid content: High and low-nicotine Burley compared to plant types with a moderate nicotine level represented by a commercial Maryland cultivar.

All plants were extracted on two successive occasions approximately two weeks apart. Duplicate samples were taken at each harvest and the protein values averaged and analyzed statistically.

Among the eight varieties, five yielded more protein from the second extraction than from the first (Fig. 7). Protein yields from the two Burley types were higher than from the other types. For the Burley Mammoth, the first extraction yielded $35 \%$ of the total protein compared to $25 \%$ for the second. The reverse was observed for low-nicotine Burley with $27 \%$ extracted the first time and $40 \%$ the second time. From these results, and those obtained from our initial experiments comparing greenhouse and field-grown tobacco, some tobacco types appear to be better candidates for recovering leaf protein than others. Both time of harvest and genotype are important factors for leaf protein production. T.I. 1329 showed a relatively good protein recovery but the residual protein value remained high, whereas Maryland Mammoth showed both low residual protein and poor protein recovery. It had been antic- 
ipated that the greater biomass of the tobacco Mammoth genotypes would provide higher protein yields. This outcome, however, was not observed, illustrating the point that biomass production per se is not an adequate criterion for predicting leaf protein yields.

\section{DISCUSSION}

Interest in tobacco leaf protein extraction has progressed from the laboratory to the pilot plant stage (6, 30). Fluctuations in tobacco leaf protein levels have been alluded to previously $(9,21)$ but the phenomenon has not been thoroughly documented under various field and greenhouse conditions. Based upon experience gained by a number of investigators, several problem areas requiring additional research have been identified. Agronomic considerations dictate that non-conventional planting and harvesting patterns are required for optimal extraction. Tobacco planted in dense populations and harvested before agronomic maturity will yield the highest protein/biomass ratio. In addition, based upon the limited varietal comparisons which have been made, commercial cultivars presently grown are not suitable candidates for protein extraction. Commercial varieties are either recalcitrant to protein fractionation or exhibit tendencies for rapid protein degradation in early stages of maturity. Selection of tobacco genotypes for protein extraction will require a thorough investigation of the available tobacco germplasm with evaluation criteria focused on suitability for protein recovery.

The present investigation examined the growth stage of tobacco for optimal protein recovery and screened a representative group of genotypes to determine their protein extraction characteristics. Even when grown under climatically controlled greenhouse conditions significant fluctuations occurred in extractable leaf pro.tein throughout the growing period. The initial procedures used in protocol $\mathrm{A}$ were evaluated and modified in protocol B to conform with techniques that could be more readily commercialized. The modified procedures allow the homogenization of leaf tissues without adding liquid - something typical laboratory blenders cannot do. Separation of liquid from the fiber was performed with a mechanical press so that the pressure could be standardized among experiments. Using this press we were able to reduce the moisture concentration of the leaf from $90 \%$ to $75 \%$. Protein not expressed remained with the fiber as insoluble protein. The amount of soluble protein fluctuated considerably more than the residual protein (Fig. 3). The residual protein associated with the fiber appeared to be quite resistant to extraction.

In contrast to most previous research on tobacco leaf protein, a prime focus of the present study was upon the amount of residual protein retained by the fiber. After pressure filtration of green juice from the homogenate the fiber still retains appreciable amounts of protein, e.g. typically $15 \%$ or more by dry weight.
Table 3.

Anion content of deproteinized brown julce extracted from tobacco leaves.

\begin{tabular}{l|c|c|c}
\hline \multirow{2}{*}{ Harvest day } & \multicolumn{3}{|c}{ Specific anion } \\
\cline { 2 - 4 } & sulfate & phosphate & nitrate \\
\hline 1 & 3.7 & 0.45 & 0.36 \\
3 & 3.3 & 0.46 & 0.21 \\
5 & 4.3 & 0.39 & 0.27 \\
8 & 7.7 & 0.31 & 0.97 \\
10 & 6.4 & 0.17 & 0.44 \\
12 & 5.3 & 0.54 & 0.09 \\
15 & 3.4 & 0.53 & 0.23 \\
17 & 3.4 & 0.54 & 0.14 \\
19 & 4.2 & 0.47 & 0.36 \\
22 & 4.9 & 0.57 & 0.36 \\
24 & 3.2 & 0.57 & 0.07 \\
26 & 5.7 & 0.87 & 0.77 \\
\hline Standard error & & & \\
of the mean & \pm 0.65 & \pm 0.06 & \pm 0.13 \\
Coefficient of & $19.7 \%$ & $13.0 \%$ & $61.9 \%$ \\
variation & & & \\
\hline
\end{tabular}

Preliminary experiments have shown that a second extraction of the fiber with weakly alkaline water can lower the Kjeldahl protein value to less than $10 \%$ by dry weight.

Isolation of the green chlorophyll-protein complex by $\mathrm{pH}$ adjustment with citric acid proved superior to the gentle heating method used in the initial procedure in that it retards oxidative browning of the homogenate. Chilling the turbid solution after removal of the green fraction appeared to accelerate the crystallization process and to slow proteolytic degradation. When the solution is subsequently heated to $80^{\circ} \mathrm{C}$, a protein precipitate forms which is analogous to Fraction II protein consisting of a mixture of denatured soluble proteins.

As shown in Fig. 3, the periodicity for protein fluctuations was approximately at 5-day intervals. Although harvesting occurred every other day in the second phase of this study it is possible that additional undetected inflections occurred between sampling dates. The fluctuations in protein concentrations could either be inherent in the plant or could be a response to changing external environmental and/or internal physiological conditions.

Previous investigations of conventionally grown tobacco had indicated that leaf protein does not decline on a large scale until at least one week prior to flowering (9). Other investigators reporting protein extraction from close-grown tobacco $(24,32)$ apparently did not detect the early decline in leaf protein concentration that was observed in the present study. Protein degradation in the densely planted tobacco commenced a full month before flowering - a limitation that must be considered when evaluating protein extraction from tobacco leaves. 
The various cultivars in widespread use over the years have presumably not been selected for protein accumulation because excessive $a$-amino nitrogen has traditionally been considered detrimental in desirable quality tobacco (14). Not enough is known about the genetic, physiological and biochemical factors that affect leaf protein metabolism and extractability. Continued research efforts to delineate these factors will be necessary if the extraction system is to be successful on a commercial scale.

\section{REFERENCES}

1. Batley, W. R., and W. J. Bray: Process for improving the nutritional value of green plant protein; U.S. Patent $* 4,130,553,1978$.

2. Bickoff, E. M., and G. O. Kohler: Preparation of edible protein from green leafy crops such as alfalfa; U.S. Patent $\$ 3,823,128,1974$.

3. Bruhn, H. D., R. J. Straub and R. G. Koegel: A systems approach to the production of plant juice protein concentrate; Proc. Int. Grain and Forage Harvesting Conf., Ames, Iowa, 1977.

4. Carlsson, R.: Selection of Centrospermae and other species for production of leaf protein concentrates; Ph. D. thesis, University of Lund, Sweden, 1975.

5. DeJong, D. W., and J. J. Lam, Jr.: Protein content of tobacco; Proc. Am. Chem. Soc. Symp. on Recent Adv. Chem. Composition Tob. and Tob. Smoke (173rd Am. Chem. Soc. Meet./Agric. \& Food Chem. Div., New Orleans, La., 1977), edited by J. L. McKenzie, pp. 78-103.

6. DeJong, D. W., and J. J. Lam, Jr.: Application of homogenized leaf curing to protein recovery and to the alteration of leaf chemistry for production of less hazardous tobacco; Tob. Res. 5 (1979) 1-27.

7. DeJong, D. W., and W. G. Woodlief: Some factors influencing tobacco leaf senescence; Beitr. Tabakforsch. Int. 10 (1979) 48-56.

8. DeJong, D. W.: Coagulation method for preparing leaf protein concentrates (LPC) from plant foliage; U.S. Patent \$4,333,871, 1982.

9. DeJong, D. W.: Factors related to maximization of protein extraction from green leaves of tobacco, Nicotiana tabacum L,; in: Progress in leaf protein research, edited by $N$. Singh, Today and Tomorrow's Printers \& Publishers, New Delhi, India, 1984, pp. 9-20.

10. Duméry, B., J. P. Albo and J. Chouteau: Analytical approach to tobacco proteins - Technological implications; Ann. Tab. (Sect. 2) 17 (1981-1982) $105 \rightarrow 132$.

11. Edwards, R. H., R. E. Miller, G. O. Kohler and D. R. McDonald: Commercial scale production of alfalfa leaf protein concentrate (Pro-Xan) - A progress report; Trans. ASAE 1979, \#79-6533.
12. Ershoff, B. H., S. G. Wildman and P. Kwanyuen: Biological evaluation of crystalline Fraction I protein from tobacco; Proc. Soc. Exp. Biol. Med. 157 (1978) 626-630.

13. Fantozzi, P., and A. Sensidoni: Protein extraction from tobacco leaves - Technological, nutritional and agronomical aspects; Qual. Plant., Plant Foods Hum. Nutr. 32 (1983) 351-368.

14. Garner, W. W.: Some aspects of the physiology and nutrition of tobacco; J. Am. Soc. Agron. 31 (1939) 459-471.

15. Gastineau, C., O. de Mathan and J. D. Dilly: Vegetable matter treatment; French Patent \#1,528, $782,1978$.

16. Gopalam, A., and R. Athinarayanan: Protein fractionation studies in flue-cured tobacco; First Int. Conf, on Leaf Protein Research, Aurangabad, India, Oct. 5-8, 1982, abstract No. 24.

17. Knuckles, B. E., and G. O. Kohler: Functional properties of edible protein concentrates from alfalfa; J. Agric. Food Chem. 30 (1982) 748-751.

18. Kung, S. D., J. A. Saunders, T. C. T'so, D. A. Vaughan, M. Womack, R. C. Staples and G. Beecher: Tobacco as a potential food source and smoke material - Nutritional evaluation of tobacco leaf protein; J. Food Sci. 45 (1980) 320-327.

19. Long, R. C.: Edible tobacco protein - Moving beyond theory: Crops Soils Mag. 36, issue 5 (1984) $13-15$.

20. Lowe, R. H.: Crystallization of Fraction I protein from tobacco by a simplified procedure; FEBS Lett. 78 (1977) 98-100.

21. Lowe, R. H., and S. J. Sheen: Accumulation of soluble proteins and nitrogenous compounds in the leaf of bright and Burley tobaccos during the growing season; Beitr. Tabakforsch. Int. 11 (1982) 161-169.

22. Nelson, F. W., G. P. Barrington, R. J. Straub and H. D. Bruhn: Design parameters for rotary extrusion macerators; Trans. ASAE 1981, \#81-1525.

23. Pirie, N. W.: Leaf protein and other aspects of fodder fractionation; Cambridge Univ. Press, London, U.K., and New York, N.Y., 1978, 183 pp.

24. Sheen, S. J.: Biomass and chemical composition of tobacco plants under high density growth; Beitr. Tabakforsch. Int. 12 (1983) 35-42.

25. Staron, T.: Le tabac - Combustible et prodigieux producteur de protéines comestibles; Méd. Nutr. 16 (1980) 337-353.

26. Straub, R. J., and R. G. Koegel: Evaluation of a cone press for forage fractionation; Trans. ASAE 1981, \$81-1527.

27. Telek, L.: Preparation of leaf protein concentrates in lowland and humid tropics; in: Tropical foods, Vol. 2, Chemistry and nutrition, edited by G. E. Inglett and G. Charalambous, Academic Press, New York, N.Y., 1979, pp. 659-684.

28. Telek, L., and H. D. Graham (eds.): Leaf protein concentrates; The AVI Publishing Company, Inc., Westport, Conn, 1983, 844 pp. 
29. Tso, T. C.: Tobacco as potential food source and smoke material; Beitr. Tabakforsch. 9 (1977) 63-66.

30. Wildman, S. G., and P. Kwanyuen: Process for isolation of ribulose 1,5-diphosphate carboxylase from plant leaves; U.S. Patent $\$ 4,268,632,1981$.

31. Wildman, S. G., P. Kwanyuen and B. H. Ershoff: Production and biological evaluation of crystalline Fraction I protein from tobacco leaves; Proc. Conf. on Nonconventional Proteins and Foods, National Science Foundation, Univ, of Wisconsin, Madison, Wis., 1977, pp. 165-171.

32. Woodlief, W. G., J. F. Chaplin, C. R. Campbell and D. W. DeJong: Effect of variety and harvest treatments on protein yield of close-grown tobacco; Tob. Sci. 25 (1981) 83-86.
33. Standard methods for the examination of water and wastewater (14th edition), edited by M. A. Franson, published jointly by Am. Public Health Assoc., Am. Water Works Assoc., and Water Pollut. Control Fed., Washington, D.C., 1976, pp. 574581.

\section{Acknowledgements}

The authors would like to gratefully ackenowledge the expert tecbnical assistance of Mary E. Engelhaxpt and Sam Garrett.

Authors' address:

Tobacco Research Laboratory,

Plant Genetics and Germplasm Institute, Beltsville Agricultwral Researcb Center, U.S. Department of Agriculture, Beltsville, Maryland, 2070S, U.S.A. 